\title{
KEBERADAAN DAN KARAKTERISASI MORFOLOGI PERONOSCLEROSPORA SPP DI SULAWESI TENGGARA
}

\section{EXISTENCE AND CHARACTERIZATION OF MORPHOLOGY PERONOSCLEROSPORA SPP IN SOUTHEAST SULAWESI}

\author{
Ekawati $^{\left.{ }^{1 *}\right)}$ L. O. S. Bande ${ }^{2)}$ Gusnawaty H.S. ${ }^{2)}$ \\ ${ }^{1)}$ Alumni Program Studi Agronomi Pascasarjana Universitas Halu Oleo \\ ${ }^{2)}$ Dosen Program Studi Agronomi Pascasarjana Universitas Halu Oleo
}

Diterima: 19 Desember 2017/Disetujui: 29 Juli 2018

\begin{abstract}
This study aims to determine the existence and morphological characteristics of Peronosclerospora spp in Southeast Sulawesi. It is carried out at the Plant Class Quarantine Laboratory of BKP Class II Kendari and five corn cultivation centers in Southeast Sulawesi from January to June 2017. The method that is done by survey followed by artificial sporulation induction is done to obtain the morphology of the fungus as a whole. Curcuma maize plant collected from 5 districts in Southeast Sulawesi Province identified morphological pathogen causes. The results showed that there are three species of Peronosclerospora in Southeast Sulawesi that have morphological characteristics identical with Peronosclerospora maydis, $P$. sorghi, and P. philipinensis.
\end{abstract}

Keyword : Peronosclerospora spp, characteristics, morphological

\section{ABSTRAK}

Penelitian ini bertujuan untuk mengetahui keberadaan dan karakteristik morfologi Peronosclerospora spp di Sulawesi Tenggara. Dilaksanakan di Laboratorium Karantina Tumbuhan BKP Kelas II Kendari dan lima daerah sentra penanaman jagung di Sulawesi Tenggara dari bulan Januari sampai bulan Juni 2017. Metode yang dilakukan yaitu dengan survei yang dilanjutkan dengan induksi sporulasi buatan dilakukan untuk memperoleh morfologi cendawan secara utuh. Tanaman jagung bergejala bulai yang dikumpulkan dari 5 kabupaten di Propinsi Sulawesi Tenggara diidentifikasi patogen penyebabnya secara morfologi. Hasil penelitian menujukkan bahwa terdapat tiga spesies Peronosclerospora di Sulawesi Tenggara yang memiliki karakteristik morfologi identik dengan Peronosclerospora maydis, P. sorghi, dan P. philipinensis.

Kata kunci: Peronosclerospora spp , karakteristik, morfologi.

\section{PENDAHULUAN}

Penyakit bulai pada tanaman jagung disebabkan oleh Peronosclerospora spp. yang merupakan penyakit utama dan paling berbahaya pada tanaman jagung di Indonesia (Semangun, 1993). Kerusakan yang disebabkan oleh patogen Peronosclerospora spp. dapat mencapai 90-100\% terutama pada varietas jagung yang rentan terhadap penyakit bulai (Burhanuddin, 2010). Patogen ini dapat menginfeksi tanaman jagung mulai dari fase awal pertumbuhan hingga umur lebih dari 21 hari setelah tanam (hst) (De Leon, 1984). Gejala dapat ditandai dengan adanya klorotik pada daun, tulang daun dan warna daun pucat, tanaman kerdil, dan tidak dapat melangsungkan proses tumbuh (De Leon, 1984). Tanaman dewasa yang terinfeksi patogen tersebut tidak dapat menghasilkan serbuk sari sehingga tanaman tidak menghasilkan buah (Gultom, 2014). Menurut Wakman dan Burhanuddin ( 2007), tanaman yang terinfeksi bulai pada umur kurang dari satu bulan tidak dapat meneruskan proses tumbuh dan secara perlahan akan mati.

Di Indonesia sampai saat ini dilaporkan ada tiga spesies Peronosclerospora yang menginfeksi tanaman jagung yaitu $P$. maydis, $P$. philippinensis, dan P. sorghi (Surtikanti, 2012). Dua dari ketiga spesies Peronosclerospora tersebut, yakni P. sorghi dan $P$. philippinensis termasuk dalam daftar organisme pengganggu tumbuhan karantina (OPTK)

\footnotetext{
${ }^{*}$ Penulis untuk korespondensi. Email: wati.eka@gmail.com
} 
kategori A2 (BKP, 2013). OPTK kategori A2 yaitu OPTK yang dilaporkan ada di wilayah Indonesia tetapi terbatas pada daerah tertentu.

Peronosclerospora maydis ditemukan menginfeksi tanaman jagung di pulau Jawa dan Kalimantan (Hikmawati, 2011), selain itu Rustiani et al ( 2015) melaporkan bahwa spesis ini sudah menginfeksi tanaman jagung di 13 provinsi di Indonesia, yaitu Jawa Timur, Jawa Tengah, DI Yogyakarta, Jawa Barat, Banten, Lampung, Bengkulu, Kalimantan Barat, Kalimantan Timur, Sulawesi Utara, Sulawesi Selatan, Nusa Tenggara Timur (NTT), dan Papua. P. sorghi ditemukan menginfeksi jagung di pulau Sumatera , Bogor, Malang, NTT dan Sulawesi Selatan sedangkan $P$. phillippinensis awalnya menginfeksi tanaman jagung di Minahasa, Sulawesi Utara (van Hoof 1953) dan saat ini dilaporkan dominan menginfeksi tanaman jagung di pulau Sulawesi, dan penyebaran spesiesnya sudah teridentifikasi di 18 kabupaten/propinsi di Indonesia (Wakman et al. 2006). Rustiani et al (2015) melaporkan spesies P. phillippinensis sudah terdapat di Lampung. Identifikasi Peronosclerospora spp. dilakukan berdasarkan ciri morfologi seperti bentuk atau ukuran spora yang dimiliki. Perbedaan deskripsi morfologi ketiga spesies Peronosclerospora pada jagung tampak pada bentuk dan ketebalan dinding kondia, jumlah percabangan konidiofor, serta ukuran konidia dan konidiofor.

Penyebaran penyakit bulai bisa terjadi sangat cepat karena konidia dapat menyebar melalui udara, sedangkan oospora dapat tersimpan lama di tanah dan dapat menyebar melalui benih (Hikmawati et al, 2011). Kemajuan teknologi memudahkan lalulintas perpindahan manusia dan barang dari satu daerah ke daerah lain. Pemasukan benih terutama benih jagung dari satu tempat ke tempat lain juga tidak bisa dihindarkan. Menurut Direktur Jendral Tanaman pangan pemanfaatan benih jagung di seluruh Indonesia mencapai 56\%. Di Sulawesi Tenggara pemasukan benih jagung pada tahun 2016 diperuntukkan penanaman lahan seluas 20.000 ha atau \pm 640.000 kilogram bibit jagung hibrida yang tersebar di 11 Kabupaten/Kota di Sulawesi Tenggara (Dirjen Tanaman Pangan, 2016).

Informasi tentang penyakit bulai di Sulawesi Tenggara masih kurang di laporkan oleh para peneliti. Penelitian terbaru dilakukan oleh Bande et al (2015) yang melaporkan bahwa patogen penyakit bulai juga menginfeksi tanaman jagung di Kabupaten Muna Barat Propinsi Sulawesi tenggara dengan intensitas penyakit sebesar $29,5 \%$. Hasil survey di lapangan pada bulan September 2016 di Desa Labone Kecamatan Lasalepa Kabupaten Muna Propinsi Sulawesi Tenggara juga diperoleh gejala penyakit bulai yang disebabkan oleh patogen Peronosclerospora spp.

Konfirmasi atas keberadaan suatu OPT/K diperlukan guna pembaruan status kategori OPT/K serta langkah pencegahan risiko pemasukan Peronosclerospora spp tersebut di wilayah Indonesia. Oleh karena itu identifikasi penyebab bulai diperlukan dalam rangka optimalisasi langkah pencegahan dampak negatif yang ditimbulkan melalui tindakan pengendalian. Identifikasi dilakukan di area sentra produksi dan bukan sentra produksi, khususnya di area perbatasan yang berpotensi terjadi introduksi OPT/K yang merugikan tersebut.

Untuk mengetahui kebaradaan dan karakteristik morfologi Peronosclerospora spp di Sulawesi Tenggara perlu dilakukan penelitian tentang keberadaan dan karakteristik Peronosclerospora di Sulawesi Tenggara.

\section{BAHAN DAN METODE}

Penelitian ini dilaksanaan di lima daerah sentra pertanaman jagung di Sulawesi Tenggara yaitu Kabupaten Muna (Kecamatan Lasalepa terdiri dari 3 desa yaitu Desa Lasalepa, Bonea, Labone dan Kecamatan Watopute terdiri dari desa Watoputi/Wali), Kabupaten Buton (Kecamatan Kapuntori terdiri dari desa Todanga, Waondowolio Lambusango dan Kecamatan Lasalimu terdiri dari desa Wasamba, Bonelalo ), Kabupaten Konawe Selatan ( Kecamatan Konda terdiri dari desa Lamomea), Kabupaten Konawe (Kecamatan Sampara terdiri dari desa Abelisa Sawah), Kota Kendari (Kecamatan Poasia terdiri dari kelurahan Andounuhu dan Kecamatan Mandonga terdiri dari Kelurahan Wawombalata), di Laboratorium BKP Kelas II Kendari.

Penelitian ini dilaksanakan pada bulan Januari sampai Juni 2017

Bahan yang digunakan dalam penelitian ini adalah tanaman jagung, kertas koran, kertas label, air bersih, tissu, larutan gula, metilen blue dan selotip. Alat yang digunakan dalam penelitian ini adalah pisau/cutter, kantung plastik, kamera, alat tulis menulis, jam, wadah air gula, plastik sampel, senter, kaca obyek, dan mikroskop cahaya.

\section{Pengambilan Sampel}

Sampel diambil dari tanaman jagung bergejala bulai di-5 kabupaten di Sulawesi Tenggara yaitu Kabupaten Muna, Buton, Konawe, Konsel dan Kota Kendari. Penentuan lokasi pengambilan sampel di dasarkan pada varietas tanaman jagung (varietas lokal) dan ada tidaknya gejala penyakit bulai pada tanaman. Metode pengambilan sampel adalah secara 
transek garis, dengan tanaman dalam satu garis pada lahan pertanaman merupakan satu petak contoh (Fachrul, 2006). Gejala bulai yang diamati adalah gejala klorosis sistemik maupun tidak sistemik, disertai dengan atau tanpa gejala seperti kipas dan/ atau kerdil yang diikuti adanya tanda massa propagul cendawan berwarna putih seperti tepung di permukaan daun bagian bawah. Tanaman jagung yang diamatai hanya pada masa pertumbuhan vegetatif. Batang tanaman bergejala yang mengandung daun kelima dari pucuk dipotong untuk kemudian dibungkus kertas koran dan dimasukkan ke dalam kantung plastik, untuk menjaga tanaman tetap segar. Tanaman segera di bawa ke ruang preparasi sampel untuk digunakan lebih lanjut pada tahap induksi sporulasi cendawan secara buatan.

\section{Induksi Sporulasi Buatan Penyebab Bulai}

Sporulasi buatan untuk menghasilkan morfologi utuh cendawan diinduksi sesuai metode Rustiani (2015). Daun tanaman dipilih sebagai sampel adalah daun ketiga dari pucuk tanaman yang memperlihatkan gejala bulai yang disertai tanda adanya massa propagul cendawan berwarna putih seperti tepung menyebar di permukaan daun bagian bawah. Sporulasi dilakukan dengan terlebih dulu memotong pangkal daun ke tiga, kemudian segera dicuci dibawah air mengalir, dengan cara menjepit daun dengan dua jari dan mengusapnya untuk memastikan stomata daun bersih dari kotoran dan propagul cendawan. Daun kemudian dikeringkan menggunakan kertas tisu pengesat. Daun yang telah kering dimasukkan ke dalam gelas berisi larutan gula $2 \%$ setinggi $1-2 \mathrm{~cm}$ dengan posisi pangkal daun berada di dasar gelas. Gelas yang telah berisi daun disungkup menggunakan plastik guna menjaga kelembaban tetap tinggi. Gelas tersebut kemudian diinkubasi pada suhu ruang selama kurang lebih 6 jam. Daun kemudian dikeluarkan dari gelas. Pangkal daun yang terendam larutan gula terlebih dulu dikeringkan dengan tisu pengesat untuk kemudian dimasukkan ke kantong plastik. Plastik diletakkan di area terbuka berumput dengan posisi permukaan daun bagian atas menghadap ke atas dan bagian bawah menghadap ke bawah. Daun diinkubasi di udara terbuka selama 7 jam. Konidia siap dipanen dengan cara mengeluarkan daun dari plastik untuk kemudian diamati bagian permukaan bawah daun. Pengamatan dilakukan dengan meletakkan daun terinfeksi di atas permukaan lampu, sehingga propagul cendawan terlihat berupa tepung berwarna putih. Propagul cendawan diambil dengan cara merekatkan selotip di atas permukaan daun, kemudian direkatkan pada kaca obyek yang sudah ditetesi pewarna methylen blue $2 \%$. Propagul diamati dibawah mikroskop cahaya dengan perbesaran hingga 1000X.

Variabel yang diamati adalah ketebalan dinding sel konidia, bentuk dan ukuran konodia, jumlah percabangan konidiofor dan bentuk konidiofor.

Data hasil pengamatan ditabulasi dan dianalisis secara deskripsi seperti yang disebutkan peneliti terdahulu (Rustiani, 2015).

\section{HASIL}

Pengambilan sampel dilakukan di-13 titik survei yang terdiri dari 5 Kabupaten/Kota di Sulawesi Tenggara. Pengamatan hasil induksi sporulasi dari area survei menunjukkan bahwa dijumpai tiga kelompok yang mempunyai perbedaan morfologi dan morfometri.

Kelompok pertama dengan karakteristik konidia berdinding tipis, bentuk konidia bulat sampai agak bulat dengan diameter 15-23 x 25-44 $\mu \mathrm{m}$ , konidiofor hialin bercabang 3-4 kali dengan panjang 150-550 $\mu \mathrm{m}$ kelompok ini identik dengan Peronosclerospora maydis. Kelompok ini terdapat di 13 titik pengambilan sampel yaitu di Desa Labone, Bonea, Lasalepa, Watopute, Bonelalo, Lambusango, Todanga, Waondowolio, Wasamba, Wawombalata, Anduonuhu, Abelisawah dan Lamomea.

Kelompok kedua dengan karakteristik konidia berdinding sel tebal yaitu $1-2 \mu \mathrm{m}$, bentuk konidia bulat sampai agak bulat dengan diameter 9$12 \times 12-13 \mu \mathrm{m}$, konidiofor tegak, menggembung dengan percabangan 2-3 kali, panjang 180-300 $\mu \mathrm{m}$. Kelompok ini identik dengan Perenosclerospora sorghi. Kelompok ini terdapat di lima titik daerah pengambilan sampel yaitu Desa Bonelalo, Lambusango, Waondowolio, Labone, dan Abelisawa.

Kelompok ketiga dengan karakteristik konidia berdinding tipis, berbentuk oval dengan diameter 10-15 x 15-38 $\mu \mathrm{m}$, konidiofor tegak, hialin dan menggelembung dengan jumlah percabangan tiga kali dengan panjang 150-300 $\mu \mathrm{m}$. Kelompok ini identik dengan Perenosclerospora philipinensis. Kelompok ini terdapat di satu titik pengambilan sampel yaitu di Desa Lasalepa. 


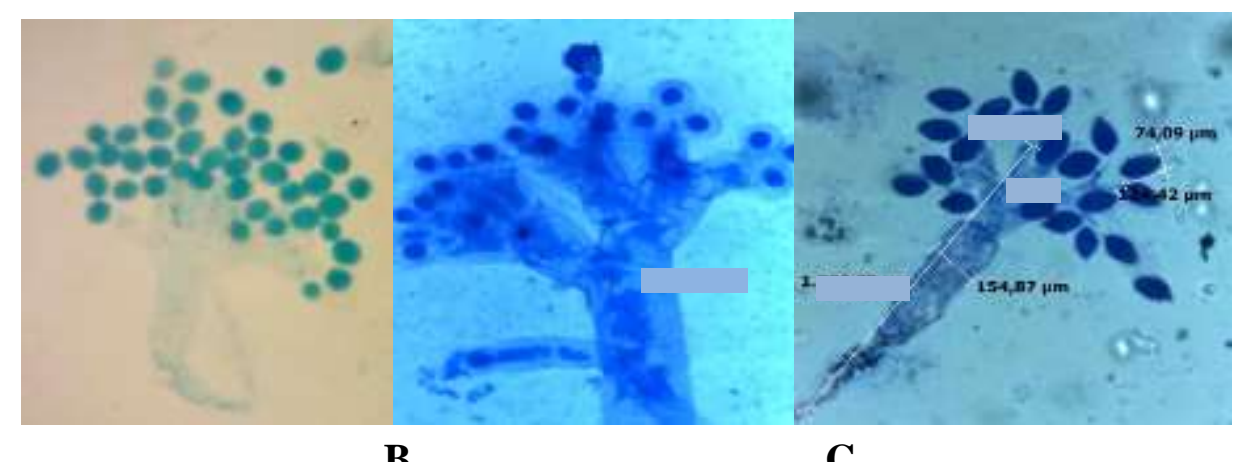

A

B

$\mathbf{C}$

Gambar 1. Konidia dan Konidiofor Peronosclerospora. maydis (A); P. sorghi (B); dan P.philippinensis (C) [Morphological of conidia and conidiophore of Peronosclerospora maydis $(A)$; $P$. sorghi (B); and P. philippinensis $(C)]$

\section{Pembahasan}

Bentuk dan ukuran konidia spesimen Peronosclerospora maydis yang ditemukan pada penelitian ini berbeda dengan morfologi yang diteliti oleh Wakman (2006), Burhanuddin (2011), dan Hikmawati et al. (2011). Wakman (2006), Burhanuddin (2011), dan Hikmawati et al. (2011) menyebutkan bahwa konidia $P$. maydis berbentuk bulat, namun konidia yang ditemukan pada penelitian ini sesuai dengan yang disebutkan oleh White (2000), dan Rustiani (2015) yaitu selain konidia berbentuk spherical (bulat) juga dijumpai berbentuk subspherical (agak bulat). Kisaran ukuran diameter Peronosclerospora maydis temuan (15-23 x 25-44 $\mu \mathrm{m})$ hampir sama dengan ukuran konidia yang diteliti oleh Rustiani (2015) yaitu 12-23 x 25-44 $\mu \mathrm{m}$. Menurut Bonde (1992) bentuk konidia spesimen $P$. maydis asal Jawa selalu globose/ spherical ketika sudah masak

Konidiofor $P$. maydis yang diamati pada penelitian ini memiliki panjang $150-550 \mu \mathrm{m}$ sedikit lebih panjang dibandingkan konidiofor yang ditemukan oleh Rustiani (2015) yang memiliki panjang 111- $410 \mu \mathrm{m}$, akan tetapi sama dengan panjang konidiofor yang dinyatakan oleh Smith dan Renfro (2002) yang menyatakan bahwa konidiofor $P$. maydis memiliki panjang $150-550 \mu \mathrm{m}$.

Kelompok ketiga terdapat di satu titik pengambilan sampel yaitu Desa Lasalepa dengan karakteristik konidia berdinding tipis, berbentuk oval berdiameter $10-15 \times 15-38 \mu \mathrm{m}$, konidiofor bercabang tiga kali dengan panjang 150-300 $\mu \mathrm{m}$. Kelompok ini identik dengan Perenosclerospora philipinensis. Hal ini sejalan dengan pendapat Rustiani (2015) yang menyatakan bahwa $P$. philipinensis memiliki konidia berdinding tipis berbentuk oval dengan diameter 11-15 x 15-40 $\mu \mathrm{m}$, jumlah percabangan konidiofor tiga kali dengan panjang 150-300 $\mu \mathrm{m}$.

Pada Tabel 8 tampak bahwa konidiofor $P$. philipinensis tegak, hyalin dan menggelembung. Hal ini sejalan dengan pendapat yang dikemukakan oleh Smith dan Renfro (2002) yang menyatakan bahwa $P$. philipinensis memiliki konidiofor tegak, hyalin dan menggelembung.

Pada hasil penelitian ini tampak bahwa $P$. maydis ada di semua daerah survey (tiga belas daerah survey) di Sulawesi Tenggara hal ini disebabkan karena $P$. maydis merupakan spesies asli Indonesia yang sudah tersebar di seluruh Wilayah Indonesia khususnya Sulawesi Tenggara. Hal ini sejalan dengan pendapat Semangun (2008) dan CABI (2014) yang menyatakan bahwa spesies $P$. maydis dikenal sebagai spesies asli Indonesia, karena dilaporkan sudah ada di Indonesia sejak 100 tahun lalu.

Berdasarkan pengamatan tampak bahwa $P$. sorghi ditemukan di Desa Labone, Abelisawah, Bonelalo, Waondowolio dan Lambusango, sedangkan $P$. philipinensis ditemukan di Desa Lasalepa. Kedua spesies ini merupakan OPTK A2 yaitu OPTK yang sudah ada di Indonesia tetapi penyebarannya terbatas di daerah tertentu di Indonesia. Masuknya OPTK A2 ini di beberapa kabupaten di Sulawesi Tenggara diduga berasal dari benih jagung daerah luar yang merupakan daerah penyebaran $P$. sorghi dan $P$. philipinensis yang masuk melalui tempat-tempat pemasukan yang belum ditetapkan oleh pemerintah, dimana tempat pemasukan tersebut belum dijaga oleh petugas karantina pertanian.

Penyebaran penyakit bulai bisa terjadi sangat cepat karena konidia dapat menyebar melalui udara, sedangkan oospora dapat tersimpan lama di tanah dan dapat menyebar melalui benih (Hikmawati et al, 2011). Terutama pada benih yang masih segar dan berkadar air tinggi. Oospora yang terdapat pada benih 
jagung, ketika ditanam pada daerah yang baru pada kondisi lingkungan yang mendukung pertumbuhannya yaitu pada keadaan lembab dan curah hujan tinggi, akan berkembang di dalam jaringan tanaman, menyerap hasil fotosintesis sehingga tanaman menjadi kerdil dan beberapa tanaman tidak menghasilkan buah. Hal ini sejalan dengan pendapat Bock and Jeger (2002) mengemukakan bahwa Peronosclerospora membentuk konidia dan oospora. Jika kedua jenis spora ini menginfeksi tanaman akan menimbulkan gejala penyakit yang sistemik dan dapat mengakibatkan sterilitas. Patogen ini akan menghasilkan konidiofor dalam jumlah banyak atau tunggal yang dilepaskan pada pagi hari melalui mulut daun atau stomata dibawah permukaan daun hal ini sejalan dengan pendapat Rustiani et al (2015) dan Quimio (1981), bahwa salah satu ciri morfologi famili Peronosporaceae adalah konidiofor yang bercabang keluar dari jaringan inang disertai konidia yang dihasilkan secara tunggal di setiap ujung percabangan konidiofor terakhir serta konidia membentuk tabung kecambah ketika berkecambah. Konidia ini akan cepat tersebar melalui udara dan angin ke tanaman jagung sehat atau tanaman jagung lokal yang ada di daerah tersebut melalui infeksi pada stomata dan lentisel hal ini sejalan dengan pendapat Semangun (1993) bahwa konidia atau konidium terbentuk di waktu malam pada waktu daun berembun dan konidium segera dipencarkan oleh angin dan Pracaya (1999) bahwa Peronosclerospora menyebar dengan konidia melalui infeksi pada stomata dan lentisel.

Untuk memperoleh data yang akurat tentang karakter Peronosclerospora spp, penelitian ini dilanjutkan dengan uji PCR.

\section{Simpulan}

Berdasarkan hasil dan pembahasan dapat ditarik kesimpulan bahwa Peronosclerospora spp sudah ada di Sulawesi Tenggara dengan karakteristik morfologi yang identik dengan Peronosclerospora maydis, $P$. sorghi dan $P$. philipinensis

\section{DAFTAR PUSTAKA}

Badan Karantina Pertanian [BKP]. 2013. Peraturan Menteri Pertanian tentang Daftar OPTK A1 dan A2 Berikut Penggolongannya, 239. Badan Karantina Pertanian. Jakarta.

Bande, L.O.S, Gusnawaty HS, dan Resman, 2015. Intensitas Penyakit yang terdapat pada Tanaman Jagung dan Kacang Tanah Dalam
Pola Tumpangsari di Pertanian Lahan Kering Kabupaten Muna Barat. Prosiding Seminar Nasional Swasembada Pangan, Jurusan Agribisnis Fakultas Pertanian UHO, PERHEPI Komisariat daerah Kendari dan Pengurus Pusat PERHEPI: 72-77.

Burhanuddin. 2010. Pengamatan penyakit bulai di Kabupaten Kediri Jawa Timur. Prosiding Seminar Ilmiah dan Pertemuan Tahunan XX, 27 Mei 2010, PEI, PFI, UPTD Balai Proteksi Tanaman Pangan dan Hortikultura Propinsi Sulawesi Selatan. Hlm.183-187.

Burhanuddin. 2011a. Proses Sporulasi Peronosclerospora philippinensis pada Tanaman Jagung. Prosiding Seminar Ilmiah dan Pertemuan Tahunan PEI dan PFI XX Komda Sul-Sel, Makassar 27 Mei 2010. Saenong S (Penyunting), 366-369. Bidang Publikasi dan Seminar ilmiah BALITSEREAL Maros.

Bock, C.H. and M.J. Jeger. 2002. The distribution and spread of sorghum downy mildew in sorghum and maize fields in Nigeria and Zimbabwe. Euro. J. Plant Pathology 108:745753.

Bonde MR, Peterson GL, Kenneth RG, Vermeulen HD, Sumartini, Bustaman M. 1992. Effect of temperature on conidial and systemic Infection of maize by Peronosclerospora species. Phytopathol. 82: 104-109.

CAB International [CABI]. 2014. Crop Protection Compendium,

http://www.cabi.org/cpc"www.cabi.org/cpc. 23 Desember 2014).

De Leon C. 1984. Maize Disease, A guide for Field Identification. Centro International de Mejoramiento de Maiz Y. Trigo. $3{ }^{\text {rd }}$ Edition. CIMMYT Mexico.

Gultom, Jhon Albert P. 2014. Penapisan Streptomyces Dari Rizosfer Jagung Untuk Pengendalian Penyakit Bulai. Skripsi Universitas Bengkulu. Bengkulu.

Hikmawati, T Kuswinanti, dan MB Pabendon. 2011. Karakterisasi Morfologi Peronosclerospora spp., Penyebab Penyakit Bulai Pada Tanaman Jagung, dari beberapa Daerah di Indonesia. Jurnal Fitomedika 7, 159-161. 
Pracaya, 1999, Hama dan Penyakit Tumbuhan, Penebar Swadaya, Jakarta.

Rustiani, U. S, 2015. Keragaman dan Pemetaan Penyebab Penyakit Bulai Jagung di 13 Provinsi Indonesia. Disertasi, Sekolah Pascasarjana Institut Pertanian Bogor, Bogor

Rustiani, U. S. Sinaga, M. S. Hidayat, S. H. Dan WijoyoS. 2015. Tiga Spesies Peronosclerospora Penyebab Penyakit Bulai Jagung di Indonesia. Program Studi Fitopatologi, Sekolah Pasca Sarjana, Departemen Proteksi Tanaman, Fakultas Pertanian. Institut Pertanian Bogor. www.ejournal.biologi.lipi.go.id. 17 September 2016.

Semangun, H, 1993. Penyakit-penyakit Tanaman Pangan di Indonesia, Gajah Mada University, Yogyakarta.

Semangun H, 2008. Penyakit-penyakit Tanaman Pangan di Indonesia, Edisi ke-2, Gadjah Mada University Press, Yogyakarta.
Surtikanti. 2012. Penyakit Bulai pada Tanaman Jagung. Di dalam: Saenong S, editor. Prosiding Seminar Ilmiah dan Pertemuan Tahunan PEI dan PFI XXI Komda Sul- Sel, Makassar 27 Desember 2011, Saenong S. (Penyunting), 41-48. Bidang Publikasi dan Seminar Ilmiah BALITSEREAL Maros.

Van Hoof, H. A., 1953. Enkele Gegevens Omtrent Sclerosapora in Indonesia ijdschr. Plziekten $36.48 \mathrm{pp}$.

Wakman W. 2006. Penyebab Penyakit Bulai Pada Tanaman Jagung, Tanaman Inang Lain, Daerah Sebaran, dan Pengendaliannya. Prosiding Seminar Ilmiah dan Pertemuan Tahunan PEI dan PFI XVI Komda Sul-Sel. Makassar 23 Mei 2005. Saenong S. (Penyunting), 36-47. Bidang publikasi dan Seminar ilmiah BALITSEREAL Maros.

White DG. 2000. Compendium of Corn Diseases. Third Edition, 78. APS Press, Minnesota. 